ENVIRONMENTAL

$\angle B O 31992$

RESTORATION

PROGRAM

\title{
Health Risk Assessment for the Building 3001 Storage Canal at Oak Ridge National Laboratory, Oak Ridge, Tennessee
}

V. Chidambariah

R. K. White 
This repont has been reproduced directly from the best avallable copy.

Avallable to DOE and DOE contractors from the Office of Scientific and Technical Information, P.O. Box 62, Oak Ridge, TN 37831; prices available from 615-576-8401, FTS 626-8401.

Avallable to the public from the National Technical Information Service, U.S. Department of Commerce, 5285 Port Royal Rd., Springtield, VA 22161. 
Environmental Restoration Division ORNL Environmental Restoration Program

\title{
Health Risk Assessment for the Building 3001 Storage Canal at Oak Ridge National Laboratory, Oak Ridge, Tennessee
}

\author{
V. Chidambariah \\ R. K. White
}

Manuscript Completed-December 1990

Date Issued-December 1991

Prepared by

Office of Risk Analysis

Oak Ridge National Laboratory

Prepared for

U.S. Department of Energy

Office of Environmental Restoration and Waste Management

under budget and reporting code EW 20

OAK RIDGE NATIONAL LABORATORY

Oak Ridge, Tennessee 37831-6285

managed by

MARTIN MARIETTA ENERGY SYSTEMS, INC.

for the

U.S. DEPARTMENT OF ENERGY

under contract DE-AC05-84OR21400

DISTHIBUTION OF THIS DOCUMENT IS UNLIMIIIEL 


\section{Author Affiliations}

V. Chidambariah and R. K. White are members of the Health and Safety Research Division, Oak Ridge National Laboratory, Martin Marietta Energy Systems, Inc. 


\section{CONTENTS}

Page

EXECUTIVE SUMMARY $\ldots \ldots \ldots \ldots \ldots \ldots \ldots \ldots \ldots \ldots \ldots \ldots \ldots$

1. INTRODUCTION $\ldots \ldots \ldots \ldots \ldots \ldots \ldots \ldots \ldots \ldots \ldots \ldots \ldots \ldots \ldots \ldots$

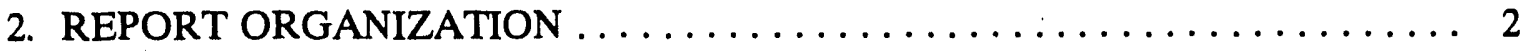

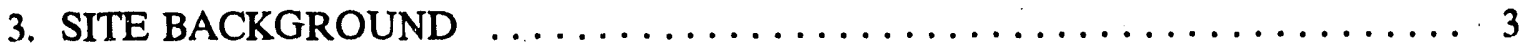

4. SITE CHARACTERIZATION $\ldots \ldots \ldots \ldots \ldots \ldots \ldots \ldots \ldots \ldots \ldots \ldots \ldots \ldots \ldots \ldots \ldots \ldots$

5. CONTAMINANT CHARACTERIZATION $\ldots \ldots \ldots \ldots \ldots \ldots \ldots \ldots$

6. ENVIRONMENTAL PATHWAYS $\ldots \ldots \ldots \ldots \ldots \ldots \ldots \ldots \ldots \ldots \ldots$

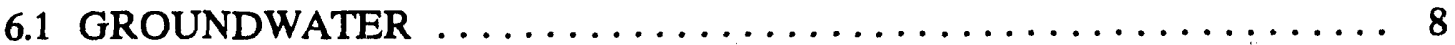

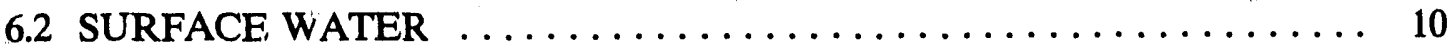

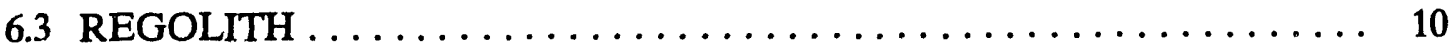

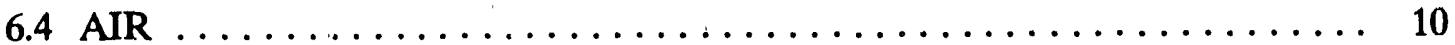

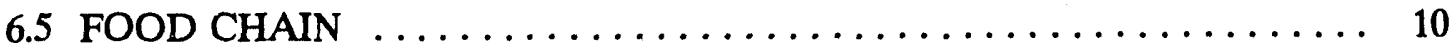

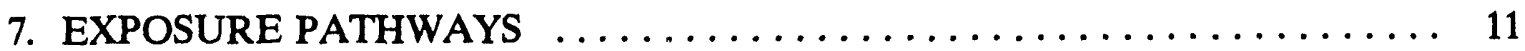

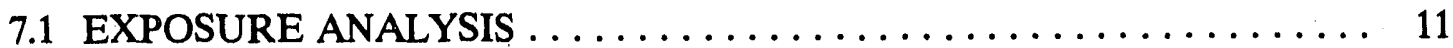

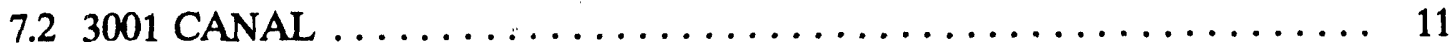

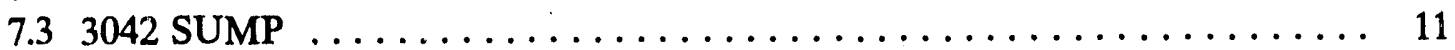

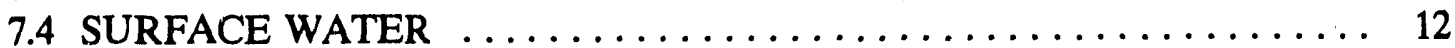

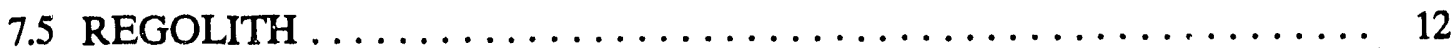

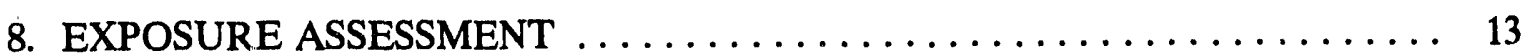

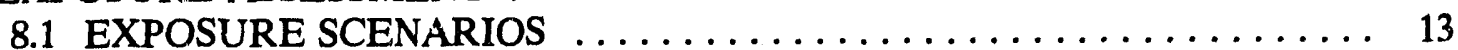

8.2 METHODOLOGY $\ldots \ldots \ldots \ldots \ldots \ldots \ldots \ldots \ldots \ldots \ldots \ldots \ldots \ldots$

8.2.1 Sediment Concentrations in the Clinch River ............ 15

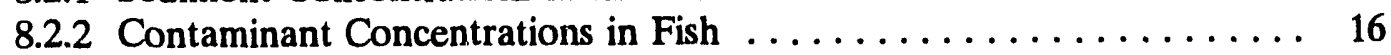

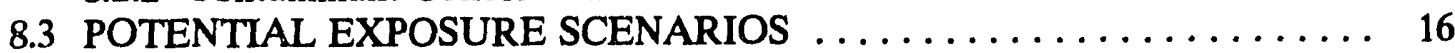

8.3.1 Ingestion of Drinking Water from the Clinch River . . . . . . . 16

8.3.2 Ingestion of Fish from the Clinch River ............... 17

8.3.3 External Exposure to Contaminated Sediments on the Shoreline . . . . 18

9. RISK CHARACTERIZATION ...................... 19

9.1 TOXICOLOGICAL EFFECTS OF THE CONTAMINANTS OF

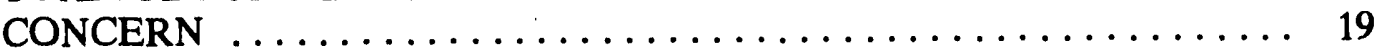

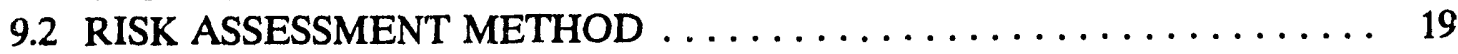

9.3 RISK ESTIMATION $\ldots \ldots \ldots \ldots \ldots \ldots \ldots \ldots \ldots \ldots \ldots \ldots \ldots \ldots \ldots$ 
10. CONCLUSIONS $\ldots \ldots \ldots \ldots \ldots \ldots \ldots \ldots \ldots \ldots \ldots \ldots \ldots \ldots \ldots \ldots$

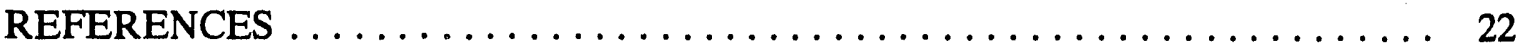

APPENDIX A.COMPARISON OF CONTAMINANT CONCENTRATIONS

WITH THEIR MCLS FOR DRINKING WATER $\ldots \ldots \ldots \ldots 23$

APPENDIX B. CURRENT SAMPLES $\ldots \ldots \ldots \ldots \ldots \ldots \ldots \ldots \ldots \ldots \ldots$

APPENDIX C. RADIATION WORK PERMITS $\ldots \ldots \ldots \ldots \ldots \ldots \ldots \ldots \ldots \ldots$ 


\section{EXECUTIVE SUMMARY}

This human health risk assessment has been prepared for the Environmental Restoration (ER) Program at the Oak Ridge National Laboratory (ORNL), Oak Ridge, Tennessee. The objectives of this risk assessment are to evaluate the alternatives for interim closure of the Building 3001 Storage Canal and to identify the potential health risk from an existing leak in the canal.

The Building 3001 Storage Canal connects Buildings 3001 and 3019. The volume of water in the canal is monitored and kept constant at about 62,000 gal. The primary contaminants of the canal water are the radionuclides ${ }^{137} \mathrm{Cs},{ }^{60} \mathrm{Co}$, and ${ }^{90} \mathrm{Sr}$; a layer of sediment on the canal floor also contains radionuclides and metals. The prime medium of contaminant transport has been identified as groundwater, which, according to dye tracer studies and examination of potentiometric surfaces, flows toward the sump in Building 3042. Sump water is pumped to Fifth Creek via storm drains. Fifth Creek drains into White Oak Creek, which drains into Clinch River.

The primary route for occupational exposure at the canal is external exposure to gamma radiation from the canal water and the walls of the canal. Similarly, the primary exposure route at the 3042 sump is external exposure to gamma radiation from the groundwater and the walls of the sump. Based on the exposure rates in the radiation work permits (Appendix C) and assuming conservative occupational work periods, the annual radiation dose to workers is considerably less than the relevant dose limits.

The potential risk to the public using the Clincn River was determined for three significant exposure pathways: ingestion of drinking water; ingestion of contaminated fish; and external exposure to contaminated sediments on the shoreline, the dominant exposure pathway. The total possible risk due to contamination from the canal leak was found to be within the acceptable risk range of $10^{-4}$ to $10^{-6}$ specified by the U.S. Environmental Protection Agency ${ }^{1}$ and negligible when compared to the existing risk levels at the Clinch River.

Although the canal poses neither a significant public health risk nor an unacceptable risk to workers, the potential health hazards of the proposed remedial alternatives for the interim corrective measure will have to be evaluated separately.

${ }^{1}$ Federal Register. 1990. Volume 55, No. 46, Mar. 8, 1990, pp. 8715-8717. 


\section{INTRODUCTION}

This human health risk assessment has been prepared for the Environmental Restoration (ER) Program at the Oak Ridge National Laboratory (ORNL), Oak Ridge, Tennessee, and is meant to aid in evaluating alternatives for interim closure of the Building 3001 Storage Canal located beneath the Oak Ridge Graphite Reactor (Building 3001). The interim closure has been planned to meet the requirements of the Resource Conservation and Recovery Act (RCRA) interim status tegulations, as outlined in the Rules of the Tennessee Department of Environment and Conservation (TDEC), Chapter 1200-1-11-05 (10)(g)4. The ójective of this risk assessment is to identify the potential health risk to the surrounding occupational population from an existing leak in the canal. The potential for any off-site impacts from the leak will also be evaluated. 


\section{REPORT ORGANIZATION}

After the introduction and site background of the Building 3001 Storage Canal, this report will characterize and evaluate the site and contaminants of potential concern. Further sections will examine the possible pathways for potential migration and exposure, followed by a detailed exposure assessment. The report will conclude with a characterization of the possible risk associated with the exposure scenarios. Relevant information for this report has been gathered from ORNL documents and personal communication with ORNL personnel. 


\section{SITE BACKGROUND}

The Building 3001 Storage Canal is L-shaped (Figs. 1 and 2) and runs south and then west to the Radiochemical Processing Plant (Building 3019). During pilot operation of the reactor, between 1943 and 1963, the canal was used to transport irradiated fuel from Building 3001 to Building 3019. First the spent uranium fuel slugs were collected in a pit at the head of the canal. Then they were transported underwater by means of an overhead crane to Building 3019. An estimated 200 slugs ruptured in the reactor core and were subsequently transferred through the canal. The contents of some of these slugs can be expected to be present in the sediment at the bottom of the canal. After shutdown of the reactor, the canal was used to store radioisotopes. An estimated 600 to 700 slugs of ${ }^{60} \mathrm{Co}$ and 14 capsules of ${ }^{90} \mathrm{Sr}$ were in the canal, but they have recently been removed. 


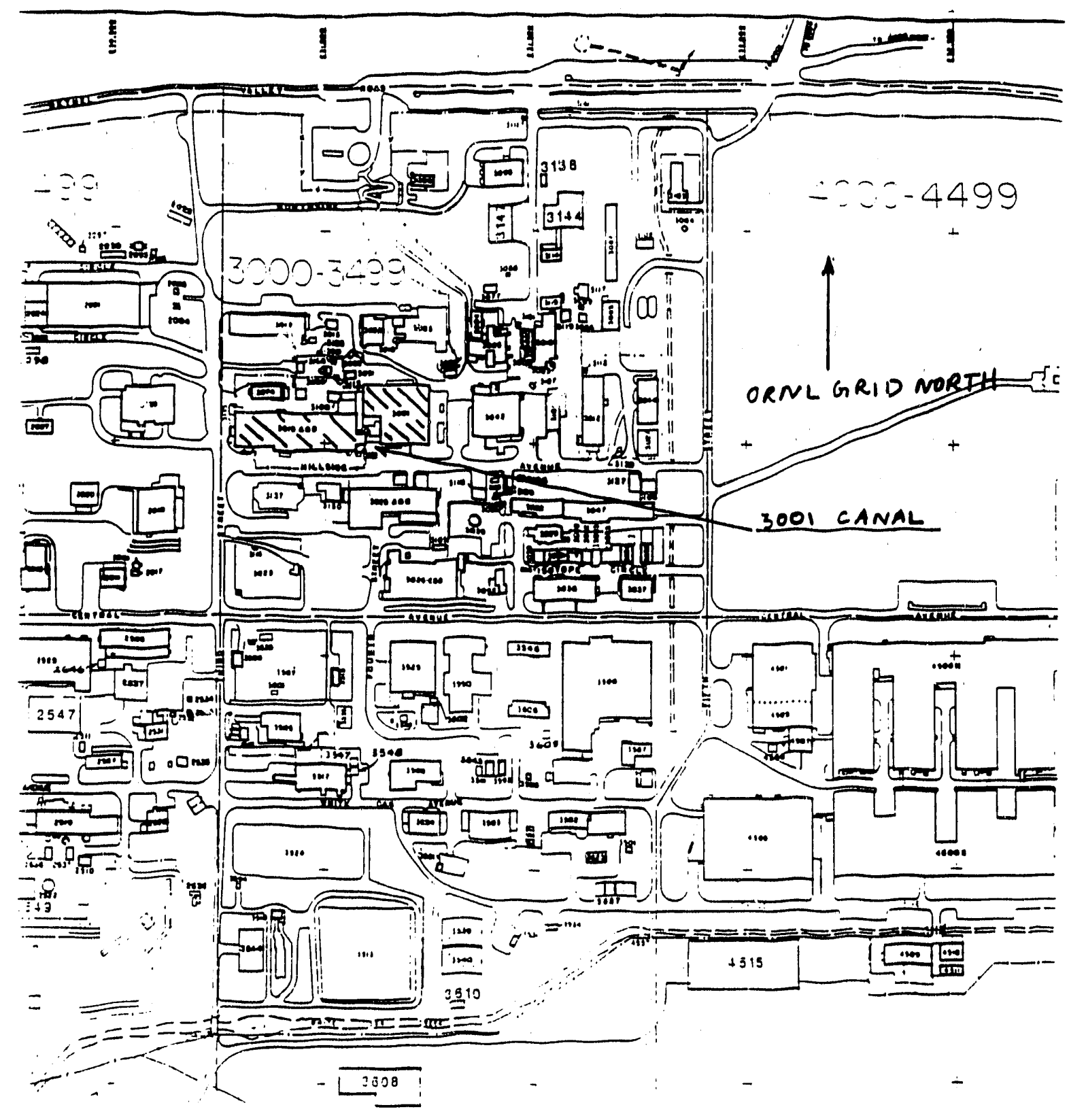

Fig. 1. Location of the Building 3001 Storage Canal. 
ORNL-DWG 76.12387R

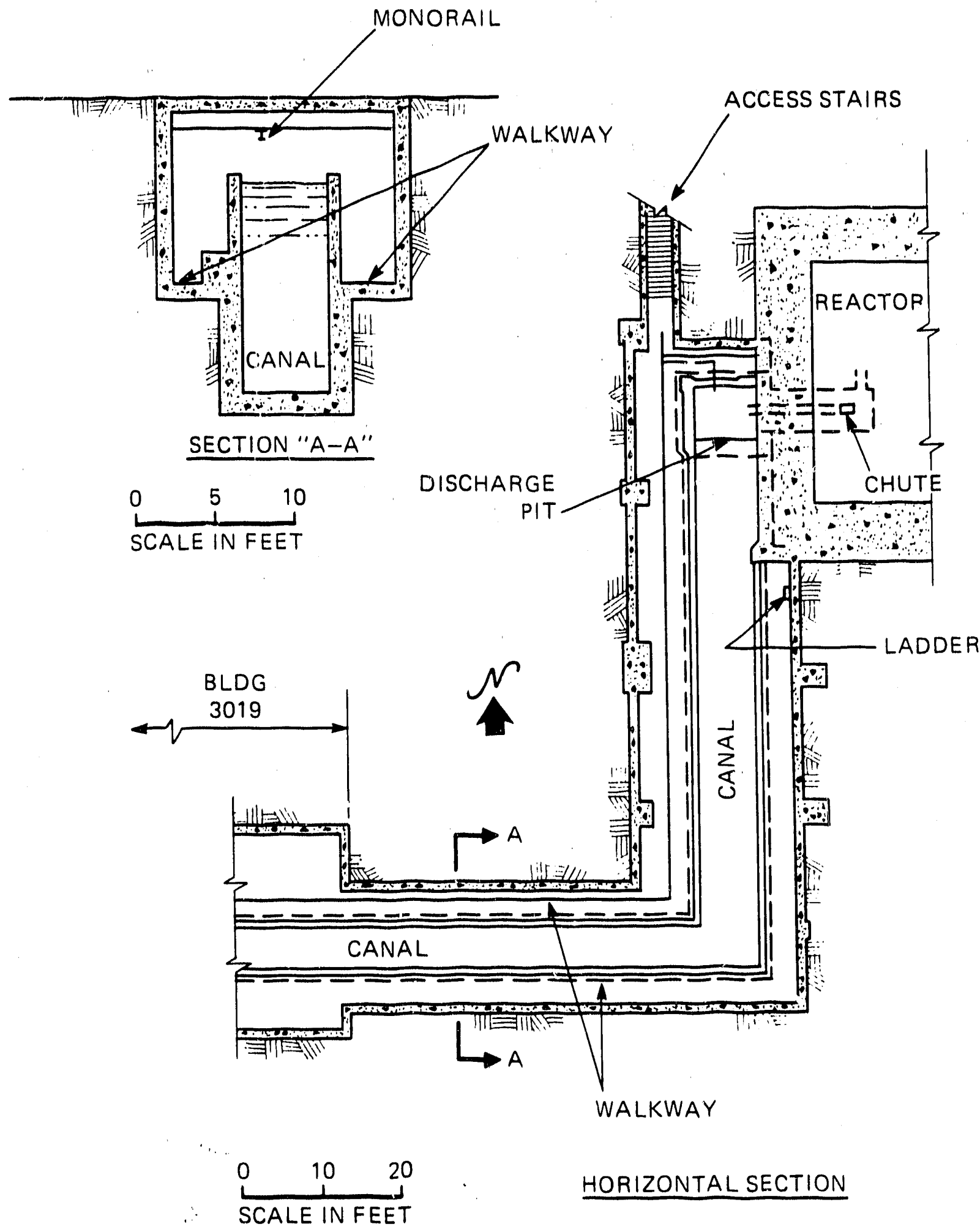

Fig. 2. The Building 3001 Storage Canal. 


\section{SITE CHARACTERIZATION}

The Building 3001 Storage Canal is located beneath Buildings 3001 and 3019 (Fig. 2). The depth of water ranges from $10.5 \mathrm{ft}$ at the head of the canal to $11.5 \mathrm{ft}$ at the other end. A pit, approximately $22 \mathrm{ft}$ deep, at the head of the canal connects the canal to the vertical chute from the reactor. It is believed that the canal leaks at the junction of the side walls and the bottom slab (V. Chidambariah, personal communication with M. Ford, ORNL, June 1990). The total volume of water is maintained at about $62,000 \mathrm{gal}$, and any volume lost due to the leak and evaporation is automatically replaced.

The primary contaminants of the canal water are the radionuclides ${ }^{137} \mathrm{Cs},{ }^{60} \mathrm{Co}$, and ${ }^{90} \mathrm{Sr}$. Airinough metal concentrations in the canal water are very low (Appendix A), a layer of sediment (about $1 / 2$ in. thick) on the canal floor also contains radionuclides and metals. Some of the metals are regulated under RCRA. The canal water is passed through an ion exchange column periodicaily, which removes radionuclides in addition to other ions. Liquid wastes from regeneration of the ion exchange column are sent to the liquid low-level waste system. 


\section{CONTAIMINANT CHARACTERIZATION}

Appendix A lists concentrations of metals and radionuclides found in the canal water. The radionuclides $-{ }^{137} \mathrm{Cs},{ }^{60} \mathrm{Co}$, and ${ }^{90} \mathrm{Sr}$-were identified as primary contaminants and were selected based on their concentrations (or activities) in the medium of concern, the canal water, and their relative toxic characteristics. The source of contaminant migration is the canal water because it has a much higher tendency to migrate by way of the leakage than does the sediment. Although the concentrations of metals in the canal water are below the Maximum Contaminant Levels (MCLs) for drinking water (see Appendix A), the sediment at the canal bottom does contain significant concentrations $\mathrm{n}$ : radionuclides and metals. The san.pling results for the canal water, the sediment, and the groundwater sump at the Oak Ridge Research Reactor Building (3042) are presented in Appendix B. The maximum possible contaminant concentrations in the canal water (Appendix B) are presented below.

\begin{tabular}{c} 
Contaminant \\
\hline${ }^{137} \mathrm{Cs}$ \\
${ }^{60} \mathrm{Co}$ \\
${ }^{90} \mathrm{Sr}$
\end{tabular}

Concentration (Bq/L)

$840(750+90)$

$290(260+30)$

$310(240+70)$ 


\section{ENVIRONMENTAL PATHWAYS}

The following section evaluates the possible pathways by which the contaminants in the canal water can migrate and reach potential receptors in the surrounding environment. The pathways that are possibly contaminated and potentially carry contaminants to receptors are the groundwater, surface water, and regolith in the vicinity of the canal. Evaluation of these pathways will include descriptions of the groundwater and surface-water flows, soil characteristics, and contaminant-specific characteristics that might affect the migration of the contaminants. Additionally, the likelihood that contaminants may be transported through the air and foodihain will be examined.

\subsection{GROUNDWATER}

Primarily, groundwater transports the leak and its contaminants. The groundwater table in the vicinity of the canal is at roughly the same elevation as the bottom of the canal. Since the canal is believed to be leaking at the junction of the side walls and the bottom slab, it is likely that the leak reaches the groundwater table without much percolation through the soil.

Dye tracer studies (D. D. Huff, ORNL, personal communications to T. E. Myrick, ORNL, Oct. 7, 1985, and June 27, 1986) have shown that when a pulse dose is injected near Building 3019, it takes a relatively short time to travel the distance to the groundwater sump in Building 3042. The dye concentration was also the highest in the groundwater sump at Building 3042, which indicates that most of the dye had travelled in that particular direction. Therefore, it can be concluded that the groundwater flows eastward in the vicinity of the canal (Fig. 3). An examination of the potentiometric surfaces in the region supports this observation. The selective flowpath is also believed to include a solution cavity along geologic strike in that region. The observed groundwater flow velocity at the sump in Building 3042 is higher than what could be expected because it assumes a pure granular flow, which indicates the presence of preferred flow in the region.

Groundwater movement has also been indicated in more pirmeable backfill along the various trench lines and pipeline cavities in the Building 3001 region. The steepest water table gradients are generally south toward White Oak Creek. However, the dye tracer studies have shown that this pathway is minor when compared with the pathway to the groundwater sump at Building 3042 . 


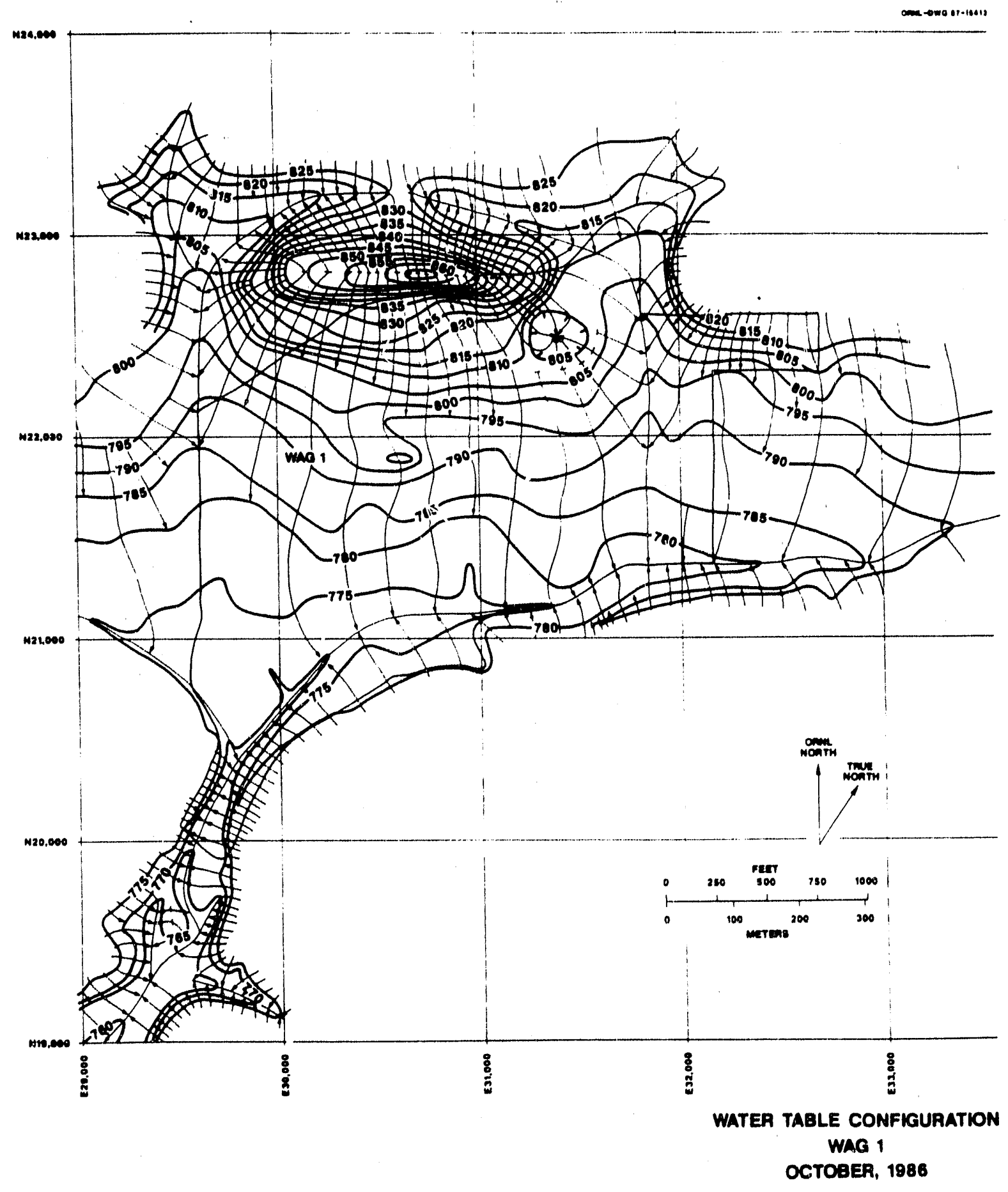

Fig. 3. Water table configuration in the Building 3001 area. 


\subsection{SURFACE WATER}

The groundwater collected in the sump at Building 3042 is pumped to Fifth Creek through the storm drains in that region, which also collect water from other outfalls in the region. Further, these storm drains collect waste water from other buildings as the water heads southward to join White Oak Creek, which drains into White Oak Lake. Eventually, White Oak Lake empties into Clinch River by way of White Oak Dam.

\subsection{REGOLITH}

As the contents of the leak are transported by the groundwater flow to the groundwater sump at Building 3042, the regolith between Buildings 3001 and 3042 probably become contaminated. Because the regolith may be expected to contain significant concentrations of radionuclides and metals, the contaminant concentrations need to be monitored in the event of future excavation.

\subsection{AIR}

In the event of excavation of the soil between Buildings 3001 and 3042, the contaminants in the regolith could be resuspended into the air. Then the air in the immediate vicinity of the excavation site can become a pathway to transport the contaminants to the receptors at the site. The potential receptors would include the working personnel at the site and in the surrounding buildings, as well as, the transient worker population in the vicinity of the site.

\subsection{FOOD CHAIN}

Under some circumstances, the food chain can provide an indirect route for contaminants to reach the public by way of the biological uptake by agricultural products sucin as grain, milk products, beef, and game animals. Bioaccumulation of contaminants through the food chain would be a significant migration pathway for the contaminants coming from a source like the ORNL plant in its entirety. But since the canal is one small unit of the ORNL complex, this pathway will not be considered. 


\section{EXPOSURE PATHWAYS}

This section will evaluate the current and potential environmental pathways of exposure to the contaminants in the canal water and will identify potential receptors. Also, assumptions and calculations will be made for the exposure assessment and the probability of exposure to receptors.

\subsection{EXPOSURE ANALYSIS}

The principal pathway of worker exposure-radiation from the stored slugs in the canal, the canal water, and the walls of the canal-is external. (Since the slugs have been removed, the exposure will te from the canal water and the canal walls.) Exposure to contaminants in the canal sediment is unlikely because of effective shielding provided by the canal water. Inhalation, another potential environmental pathway, which is dependent upon excavation of the regolith in the area between Buildings 3001 and 3042, will also be considered because of public exposure at the Clinch River to the contaminants.

The existence of an exposure pathway (i.e., a link between the contaminated medium and the receptor) establishes the probability of exposure, regardless of the contaminant concentrations in the medium. However, the presence of a completed exposure pathway does not necessarily imply adverse health effects, which are also dependent upon exposure factors and the concentrations and toxicolugical properties of the contaminants involved. (The likelihood of the occurrence of adverse health effects will be discussed in the Risk Characterization section.)

Following are descriptions of human exposure routes for each environmental pathway identified in the previous section. Each exposure route is delineated with regard to current or potential exposures that may result from each of these environmental pathways.

\subsection{BUILDING 3001 CANAL}

The canal is a potential source of occupational exposure, which could occur through direct radiation from the stored slugs in the canal, the canal water, and the canal walls. (With the slugs removed, exposure is only from the canal water and the canal walls.)

\subsection{BUILDING 3042 SUMP}

Maintenance personnel are the potential receptors of external radiation exposure that could occur at the groundwater sump in Building 3042. The principal sources of radiation would be the groundwater collected in the sump and the walls of the sump. 


\subsection{SURFACE WATER}

The groundwater from the sump in Building 3042 is pumped to Fifth Creek through the storm drains, which carry water from other sources in the Building 3001 area. Although it is unlikely that external exposure could occur at any point along the line of travel-Building 3042 to Fifth Creek, into White Oak Creek and White Oak Lake, and finaliy draining into the Clinch River-exposure could possibly occur through ingestion of contaminated fish in the Clinch River and through external exposure to contaminated sediment on the shoreline.

\subsection{REGOLITH}

If the area between Buildings 3001 and 3042 is excavated, exposure could occur through inhalation of resuspended dust and through direct radiation from the excavated soil. To assess the exposure to potential receptors (i.e., excavation personnel, the working population in the immediate vicinity, and the transien worker population), contaminant concentrations in the soil will have to be determined. Currently, concrete pavement makes this scenario irrelevant; however, this potential for exposure should be evaluted before any future soildisturbing activities are initiated. 


\section{EXPOSURE ASSESSMENT}

To quantify the exposures to the potential receptors described in the previous section, a series of exposure scenarios are developed and evaluated to conservatively estimate the exposure to contaminants originating from the leak in the canal. Quantitative estimates of exposure are derived from contaminant concentrations in the environmental media, assumptions about frequency of exposure, and estimates of human intake for the pertinent exposure pathways.

\subsection{EXPOSURE SCENARIOS}

Exposure scenarios have been developed to define current plausible situations in which potential exposure to the contaminants from the canal could take place. To assess the potential exposure, the following scenarios will be used.

1. Maintenance worker at the canal: Occupational exposure to external radiation at the Building 3001 canal.

2. Maintenance worker at the Building 3042 sump: Occupational exposure to external radiation at the Building 3042 sump.

3. Public exposure at the Clinch River: Drinking water, fish ingestion, sediment exposure.

\subsection{METHODOLOGY}

The health effects associated with occupational exposures at the canal and the Building 3042 sump will be determiried by estimating and comparing the annual whole-body dose in mrem with the relevant health-based standards. Also, the relative risks associated with the exposures and the standard will be calculated and compared. For example, the possible health effects from public exposure at the Clinch River will be determined by estimating the

lifetime excess cancer risk. A comparison will be made between the total dose estimate and the Nuclear Regulatory Commission (NRC) standard for continuous public exposure from the management of high-level and transuranic radioactive waste at U.S. Department of Energy (DOE) facilities.

\section{Maintenance worker at the canal: Occupational exposure to external radiation from canal water}

This scenario conservatively estimates the possibility of exposure to personnel working at the Building 3001 Storage Canal site. Even though maintenance workers are in the canal area only to perform particular tasks, they are required to obtain radiation work permits and are monitored for radiation exposure before and after the job (V. Chidambariah, personal communication with M. Ford, ORNL, 1991). The estimated exposure readings from the radiation work permits (Appendix $C$ ) indicate an exposure rate of less than one $\mathrm{mrem} / \mathrm{h}$ in the canal area. 
If we assume an exposure rate of one $\mathrm{mrem} / \mathrm{h}$ and a normal occupational work period of $2,000 \mathrm{~h} /$ year $(40 \mathrm{~h} /$ week $\times 50$ week/year), the total annual radiation dose would amount to 2000 mrem, which is less than the annual occupational dose limit of 5480.11 set by the DOE for its radiation workers. The annual radiation dose limit for occupational exposures set by the NRC (10 CFR 20, 1960 and 1986) is 5000 mrem. Since the actual exposure period is considerably smaller than $2000 \mathrm{~h} / y e a r$, the total annual radiation dose to workers is considerably less than 2000 mrem.

\section{Maintenance worker at the Building 3042 sump: Occupational expasure to direct radiation from groundwater}

This scenario conservatively estimates the possible exposure to maintenance workers in the sump at Building 3042. Again, there are no maintenance workers at the sump on a continuous basis; hence, when entering the sump area for a specific task, workers are monitored for radiation exposure before and after the job. Typically, radiation exposures on such occasions have been in the range of $0-1$ mrem (V. Chidambariah, personal communication with G. Coleman, ORNL, 1991).

Assuming a typical occupational period of $2000 \mathrm{~h} /$ year and an exposure rate of $1 \mathrm{mrem} / \mathrm{h}$, the total annual dose would be $2000 \mathrm{mrem}$, which is within the relevant safety limits for radiation exposure. The actual radiation dose to a worker at the sump is expected to be considerably less than $2000 \mathrm{mrem} / \mathrm{year}$ because of smaller exposure periods.

\section{Public exposure at the Clinch River}

In this scenario, the possible public exposure to the contaminants from the canal through ingestion of drinking water and contaminated fish from the Clinch River and external exposure to sediments on the shoreline will be evaluated. Since drinking water from the Clinch River undergoes treatment before distribution, it will not be considered in the exposure and risk computations.

In evaluating the contaminant concentrations in the Clinch River, three assumptions will be made: the leak enters the groundwater system in the Building 3001 area and is carried to White Oak Creek and subequently to the Clinch River; the contaminants undergo successive dilution with no sorption to any solid particles as they travel to the Clinch River; and these contaminants concentrate in the sediments and bioaccumulate in the fish.

To calculate the contaminant concentrations in the Clinch River, the flow in Fifth Creek will be assumed to consist entirely of the groundwater flow from the Building 3001 area. The following steps illustrate the process:

$$
\mathrm{X} 0(\mathrm{~Bq} / \mathrm{L}) \times \frac{\text { canal leak rate }}{\text { groundwater flow }}=\mathrm{X} 1(\mathrm{~Bq} / \mathrm{L})
$$




$$
\begin{gathered}
X 1(\mathrm{~Bq} / \mathrm{L}) \times \frac{\text { groundwater flow }}{\text { WOC fiow }}=\mathrm{X} 2(\mathrm{~Bq} / \mathrm{L}) \\
\mathrm{X} 2(\mathrm{~Bq} / \mathrm{L}) \times \frac{\text { WOC flow }}{\text { CR flow }}=\mathrm{X} 3(\mathrm{~Bq} / \mathrm{L})
\end{gathered}
$$

where

X0 = contaminant concentration in the canal,

$\mathrm{X} 1=$ contaminant concentration at the Building 3042 sump and Fifth Creek,

$\mathrm{X} 2=$ contaminant concentration in White Oak Creek,

X3 = contaminant concentration in the Clinch River,

WOC = White Oak Creek,

$\mathrm{CR} \quad=$ Clinch River.

The estimated values for the various flow rates are listed below. The flow rates for White Oak Creek and Clinch River are the estimated average daily flows for the year 1987 (Rogers et al., 1987).
Canal leak
400 gpd
Groundwater flow 10,000 gpd
$\begin{array}{ll}\text { WOC flow } & 2.6 \mathrm{E}+07 \mathrm{gpd} \\ \text { Clinch River flow } & 11.3 \mathrm{E}+09 \mathrm{gpd}\end{array}$

\begin{tabular}{|c|c|c|c|c|}
\hline Contaminant & Xo & $\mathbf{X} 1$ & $\mathbf{X} 2$ & $\mathbf{X 3}$ \\
\hline${ }^{137} \mathrm{Cs}$ & 840 & 33.6 & $1.3 \mathrm{E}-02$ & 2.8E-05 \\
\hline${ }^{60} \mathrm{Co}$ & 290 & 11.6 & 4.5E-03 & $9.8 \mathrm{E}-06$ \\
\hline${ }^{90} \mathrm{Sr}$ & 310 & 12.4 & $4.8 \mathrm{E}-03$ & 1.1E-05 \\
\hline
\end{tabular}

The calculated contaminant concentrations $(\mathrm{Bq} / \mathrm{L})$ are presented below:

\subsubsection{Sediment Concentrations in the Clinch River}

To estimate exposure to canal contaminants on the shoreline of the Clinch River, the sediment concentrations resulting from the settling of dissolved contaminants needs to be determined. These concentrations can be conservatively estimated as the product of the dissolved concentration and the distribution coefficient, $K_{d}$, for the particular contaminant (assuming that all suspended particles will settle down).

sediment concentration $(\mathrm{pCi} / \mathrm{kg})=\mathrm{K}_{d}(\mathrm{~L} / \mathrm{kg}) \times$ river concentration $(\mathrm{pCi} / \mathrm{L})$.

Strontium-90 will not be considered for this pathway because it is a beta emitter and would not be a significant source of external exposure. 
The estimated average values of the distribution coefficients $\left(K_{d} s\right)$ for the contaminants at the mouth of the Clinch River (Olsen et al., 1990) and their calculated concentrations in the sediments are presented below:

\begin{tabular}{|c|c|c|c|}
\hline Contaminant & $\mathrm{K}_{\mathrm{d}}(\mathrm{L} / \mathrm{kg})$ & X3 (pCi/L) & $\mathrm{X}_{1},(\mathrm{pCi} / \mathrm{kg})$ \\
\hline${ }^{137} \mathrm{Cs}$ & 2.7E+05 & $7.6 \mathrm{E}-04$ & 205 \\
\hline${ }^{60} \mathrm{Co}$ & $3.3 E+04$ & 2.7E-04 & 9 \\
\hline
\end{tabular}

\subsubsection{Contaminant Concentrations in Fish}

Contaminant concentrations in whole fish can be calculated as the product of the dissolved equilibrium concentration of the contaminant and the bioconcentration factor $(\mathrm{BCF})$ for the contaminant in a particular species of fish. For the Clinch River system, the generic bioconcentration factors for freshwater fish (International Atomic Energy Agency Series: 57) will be considered as representative factors for the contaminants of concern.

\begin{tabular}{|c|c|c|c|}
\hline Contaminant & BCF (L/kg) & $\mathrm{X} 3(\mathrm{pCi} / \mathrm{L})$ & $\mathrm{X}_{\mathbf{f}}(\mathrm{pCi} / \mathrm{kg})$ \\
\hline${ }^{137} \mathrm{Cs}$ & 2000 & $7.6 \mathrm{E}-04$ & $1.5 \mathrm{E}+00$ \\
\hline${ }^{60} \mathrm{Co}$ & 300 & 2.7E-04 & 8.1E-02 \\
\hline${ }^{90} \mathrm{Sr}$ & 60 & $3.0 \mathrm{E}-04$ & $1.8 \mathrm{E}-02$ \\
\hline
\end{tabular}

\subsection{POTENTIAL EXPOSURE SCENARIOS}

Public exposure to contaminants in the Clinch River can occur through several pathways. The three most significant are

- ingestion of drinking water from the Clinch River,

- ingestion of fish from the Clinch River, and

- external exposure to contaminated sediments on the shoreline.

\subsubsection{Ingestion of Drinking Water from the Clinch River}

A person is assumed to consume $2 \mathrm{~L}$ of untreated water per day from the Clinch River for a period of 70 years, which is the average lifetime of a person living in the United States. The lifetime intake in picocuries is calculated as the product of the contaminant concentration in the river and the lifetime intake of water, in liters, as follows:

$2(\mathrm{~L} / \mathrm{d}) \times 365(\mathrm{~d} /$ year $) \times 70($ years $)=51,100 \mathrm{~L} ;$

lifetime contaminant intake $(\mathrm{pCi})=$ contaminant concentration $(\mathrm{pCi} / \mathrm{L}) \times$ lifetime water intake (L) ; 
lifetime dose $(\mathrm{mrem})=$ lifetime contaminant intake $(\mathrm{pCi}) \times$ dose conversion factor $(\mathrm{mrem} / \mathrm{pCi})$.

The lifetime intakes and the corresponding doses for the contaminants are listed below.

\begin{tabular}{|c|c|c|c|}
\hline Contaminant & $\begin{array}{l}\text { Lifetime intake } \\
\text { (pCi) }\end{array}$ & $\begin{array}{c}\text { Dose conversion factor } \\
\text { (mrem/pCi) }\end{array}$ & $\begin{array}{l}\text { Lifctime Dose } \\
\text { (mrem) }\end{array}$ \\
\hline${ }^{137} \mathrm{Cs}$ & 39 & $5.0 \mathrm{E}-05$ & $2.0 \mathrm{E}-03$ \\
\hline${ }^{60} \mathrm{Co}$ & 14 & 2.7E-05 & $3.8 \mathrm{E}-04$ \\
\hline${ }^{90} \mathrm{Sr}$ & 16 & $1.4 \mathrm{E}-04$ & $2.2 \mathrm{E}-03$ \\
\hline & & & $4.6 \mathrm{E}-03$ \\
\hline
\end{tabular}

This dose compares to the EPA drinking water standard of 4 mrem/year $(280 \mathrm{mrem}$ lifetime).

\subsubsection{Ingestion of Fish from the Clinch River}

A person is assumed to consume contaminated fish at an average rate of $6.5 \mathrm{~g} / \mathrm{d}$ (EPA, 1989) for a lifetime period of 70 years. (The loss of contaminants through dressing and cooking the fish will not be considered in the exposure estimation.) The lifetime dose of exposure from this pathway is computed as follows:

lifetime fish intake $=6.5(\mathrm{~g} / \mathrm{d}) \times 365(\mathrm{~d} /$ year $) \times 70($ year $)=166,075 \mathrm{~g}=166 \mathrm{~kg} ;$

lifetime contaminant intake $(\mathrm{pCi})=$ contaminant concentration in fish $(\mathrm{pCi} / \mathrm{kg}) \times$ lifetime fish intake $(\mathrm{kg})$;

lifetime dose $(\mathrm{mrem})=$ lifetime intake $(\mathrm{pCi}) \times$ dose conversion factor $(\mathrm{mrem} / \mathrm{pCi})$.

The lifotime intakes and the corresponding doses for the contaminants are listed here.

\begin{tabular}{|c|c|c|c|}
\hline Contaminant & $\begin{array}{l}\text { Lifetime intake } \\
\text { (pCi) }\end{array}$ & $\begin{array}{l}\text { Dose conversion factor } \\
\text { (mrem/pCi) }\end{array}$ & $\begin{array}{c}\text { Lifetime Dose } \\
\text { (mrem) }\end{array}$ \\
\hline${ }^{137} \mathrm{Cs}$ & 252 & $5.0 \mathrm{E}-05$ & $1.3 \mathrm{E}-02$ \\
\hline${ }^{60} \mathrm{Co}$ & 14 & 2.7E-05 & $3.8 \mathrm{E}-04$ \\
\hline \multirow[t]{2}{*}{${ }^{90} \mathrm{Sr}$} & 3 & $1.4 \mathrm{E}-04$ & $\underline{4.2 E-04}$ \\
\hline & & & $1.4 \mathrm{E}-02$ \\
\hline
\end{tabular}




\subsubsection{External Exposure to Contaminated Sediments on the Shoreline}

The source of contamination for sediments on the shoreiine is assumed to be of infinite lateral extent with a uniform depth of $10 \mathrm{~cm}$. The exposure concentrations of the contaminar ts in units of picocuries per kilogram will be converted to units of picocuries per square meter by assuming a uniform surface density of $143 \mathrm{~kg} / \mathrm{m}^{2}$ (EPA, 1989). The resulting Committed Effective Dose Equivalent will be calculated using the appropriate dose conversion factor. The duration of exposure will be conservatively assumed to be $1000 \mathrm{~h} /$ year (Hoffman et al., 1990) for a period of 70 years.

The modifying exposure factor $(E F)=1000 \mathrm{~h} /(365 \times 24) \mathrm{h}=0.11$.

The following equation describes the lifetime dose calculation:

committed effective dose equivalent $(\mathrm{mrem})=$ exposure concentration $\left(\mathrm{pCi} / \mathrm{m}^{2}\right) \times 1 / 10,000\left(\mathrm{~m}^{2} / \mathrm{cm}^{2}\right) \times$ dose conversion factor $\left(\mathrm{mrem} \cdot \mathrm{year}^{-1} / \mathrm{pCi}\right.$ -

$\left.\mathrm{cm}^{-2}\right) \times$ exposure period (year) $\times$ exposure factor .

The contaminant concentrations accompanied by their dose calculations are presented below.

\begin{tabular}{|c|c|c|c|}
\hline Contaminant & $\begin{array}{l}\text { Exposure concentration } \\
\left(\mathrm{pCi} / \mathrm{cm}^{2}\right)\end{array}$ & 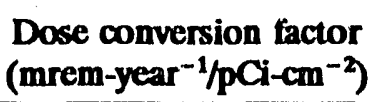 & $\begin{array}{l}\text { Lifetime Dose } \\
\text { (mrem) }\end{array}$ \\
\hline${ }^{137} \mathrm{Cs}$ & 2.9 & $5.98 \mathrm{E}-01$ & 13 \\
\hline \multirow[t]{2}{*}{${ }^{60} \mathrm{CO}$} & 0.1 & $2.31 E+00$ & $\underline{2}$ \\
\hline & & & 15 \\
\hline
\end{tabular}

This dose compares to the NRC standards of 25 mrem/year at DOE disposal facilities and 100 mrem/year public exposure from all sources at DOE facilities (40 CFR 191, 1985). 


\section{RISK CHARACTERIZATION}

This section integrates the toxicological properties of the contaminants of concern, estimates and compares risks from these contaminants to the acceptable cancer risk range specified by the EPA, and analyzes the risk to the receptors in each exposure scenario. This risk estimation will be limited to the public use of Clinch River.

\subsection{TOXICOLOGICAL EFFECTS OF THE CONTAMINANTS OF CONCERN}

The contaminants of concern are the radionuclides ${ }^{137} \mathrm{Cs},{ }^{60} \mathrm{Co}$, and ${ }^{90} \mathrm{Sr}$. The radiation from the disintegrations of these radionuclides consists mainly of beta and gamma radiation. Because this form of radiation has greater penetration than alpha particles, a person can be exposed to it without actually coming in direct contact with the source (e.g., inhalation, ingestion, or dermal contact).

The primary adverse biological effects associated with ionizing radiation exposures from radioactive substances in the environment are carcinogenicity, the ability to produce cancer; mutagenicity, the ability to cause mutations in somatic and germ cells; and teratogenicity, the ability to cause permanent structural or functional deviations during the growth of the embryo.

The studies on carcinogenicity are the most quantitative and well documented. Studies on human populations and laboratory animals have shown that as radiation doses increase, so too does the cancer incidence or mortality. Ionizing radiation can be considered a complete carcinogen in that it acts both as initiator and promoter; it can induce cancer in nearly every tissue and organ. In the estimation of cancer risk, it is assumed that no threshold exists for radiation carcinogenesis.

\subsection{RISK ASSESSMENT METHOD}

This section describes the methodology for estimating the lifetime excess fatal cancer risk due to exposure to the contaminants by different pathways. The lifetime excess fatal cancer risk for occupational and public exposures is calculated as the product of the nominal probability coefficient [7.5E-07 $\mathrm{mrem}^{-1}$ for the public (ICRP, 1991)] and the lifetime dose (mrem). This coefficient represents the probability of total cancer fatality (weighted sum of fatal and nonfatal cancers) per unit effective dose equivalent. The data from which this factor is derived, represents a whole population consisting of different age groups and equal numbers of men and women. The sum of risks from all pathways will represent the total possible excess fatal cancer risk to an individual using the Clinch River. 


\subsection{RISK ESTIMATION}

For occupational exposures at the canal, the annual dose to an average worker would be considerably less than 2000 mrem because of considerably smaller exposure periods. Also, ALARA (As Low As Reasonably Achievable) practices at DOE facilities would keep the dose rates to workers considerably lower than the dose limits.

For public exposures, it can be seen that the total dose due to external exposure to the sediments dominates the dose received through the drinking water and fish ingestion pathways. Therefore, the lifetime excess fatal cancer risk due to external exposure to contaminated sediments will also dominate the risk from other pathways. The lifetime excess fatal cancer risk for all pathway's is presented below.

\begin{tabular}{|c|c|c|c|}
\hline Pathway & $\begin{array}{c}\text { Total dose } \\
\text { (mrem) }\end{array}$ & $\begin{array}{l}\text { Risk factor } \\
\left(\mathrm{mrem}^{-1}\right)\end{array}$ & Lifetime risk \\
\hline Drinkin;y water & 4.6E-03 & 5.0E-07 & 2.3E-09 \\
\hline Fish ingestion & $1.4 \mathrm{E}-02$ & $5.0 \mathrm{E}-07$ & 7.3E-09 \\
\hline \multirow[t]{2}{*}{ External exposure } & 15 & $5.0 \mathrm{E}-07$ & 7.3E-06 \\
\hline & & & 7.3E-06 \\
\hline
\end{tabular}




\section{CONCLUSIONS}

There appears to be no significant health risk from the Building 3001 Storage Canal. The annual occupational radiation dose at the canal is well below relevant health based limits for occupational exposures. The potential lifetime excess cancer risk estimated for the hypothetical worker is at an acceptable level. The potential risk to the public using the Clinch River was estimated for three significant exposure pathways using conservative exposure assumptions. The public risk due to external exposure to contaminated sediments on the shoreline was found to dominate the risk from other exposure pathways. The potential public risk resulting from contamination from the canal leak is (1) within the acceptable risk range of $10^{-4}$ to $10^{-6}$ specified by the EPA (Federal Register, 1990) and (2) negligible when compared to the existing risk levels at the Clinch River (Hoffman et al., 1990, Appendix C). However, the health risks associated with each of the proposed remedial alternatives for the interim corrective measure will have to be evaluated before deciding upon the final remedy. 


\section{REFERENCES}

EPA (Environmental Protection Agency). 1989. Risk Assessment Guidance for Superfund. Vol 1: Human Health Evaluation Manual. U.S. Environmental Protection Agency, Washington D.C.

Federal Register. 1990. Vol. 55, No. 46, Mar. 8, 1990, pp. 8715-8719.

Gilbert, T. L., et al. 1985. A Manual for Implementing Residual Radioactivity Guidelines. September 1985 review draft. Prepared for the U.S. Department of Energy. Tables 3.1 and 3.2.

Hoffman, F. O., et al. 1990. Preliminary Screening of Contaminants in the Off-Site Surface Water Environment Downstream of the U.S. Department of Energy Oak Ridge Reservation. ORNL/ER-9 (March 1990 review draft). Table 2.2.

ICRP (International Commission on Radiological Protection). 1991. Annals of the ICRP. Vol. 21, No. 1-3. Tables 3 and 5.3.

Olsen, C. R., et al. 1990. Transport and Accumulation of Cesium-137 and Mercury in the Clinch River and Watts Bar Reservoir System. ORNL/ER-7 (March review draft). Table 5, p. 24.

Rogers, J. G., et al. 1988. Environmental Surveillance of the U.S.D.O.E. Oak Ridge Reservation and Surrounding Environs During 1987, vol 1: Narrative, Summary, and Conclusions. ES/ESH-4/V1. Table 2.2.8, p. 60. 


\section{APPENDIX A \\ COMPARISON OF CONTAMINANT CONCENTRATIONS WITH THEIR MCLS FOR DRINKING WATER}




\section{COMPARISON OF CONTAMINANT CONCENTRATIONS WITH THEIR MCLS} FOR DRINKING WATER

\begin{tabular}{|c|c|c|c|}
\hline Contaminant & $\begin{array}{l}\text { Canal water surface } \\
\text { concentration }(\mathrm{mg} / \mathrm{L})\end{array}$ & $\begin{array}{l}\text { ORR groundwater sump } \\
\text { concentration }(\mathrm{mg} / \mathrm{L})\end{array}$ & $\begin{array}{l}\text { Dripling Water } \\
\text { MCIL (mg/L)" }\end{array}$ \\
\hline $\mathrm{Ag}$ & $<5.0 \mathrm{E}-03$ & $<5.0 \mathrm{E}-03$ & $5.0 \mathrm{E}-02$ \\
\hline As & $<5.0 \mathrm{E}-02$ & $<5.0 \mathrm{E}-02$ & $5.0 \mathrm{E}-02$ \\
\hline $\mathrm{Ba}$ & $<2.0 \mathrm{E}-03$ & $4.9 \mathrm{E}-02$ & $1.0 \mathrm{E}+00$ \\
\hline $\mathrm{Cd}$ & $<7.0 \mathrm{E}-03$ & $<7.0 \mathrm{E}-03$ & $1.0 \mathrm{E}-02$ \\
\hline $\mathrm{Cr}$ & $<4.0 \mathrm{E}-03$ & 1.1E-02 & $5.0 \mathrm{E}-02$ \\
\hline $\mathrm{Pb}$ & $<5.0 \mathrm{E}-02$ & $<5.0 \mathrm{E}-02$ & $5.0 \mathrm{E}-02$ \\
\hline $\mathrm{Se}$ & $<4.0 \mathrm{E}-02$ & $<4.0 \mathrm{E}-02$ & $1.0 \mathrm{E}-02$ \\
\hline $\mathrm{Hg}$ & $2.4 \mathrm{E}-04$ & & $2.0 \mathrm{E}-03$ \\
\hline${ }^{137} \mathrm{Cs}$ & $680 \pm 60 \mathrm{~Bq} / \mathrm{L}$ & $<2 \mathrm{~Bq} / \mathrm{L}$ & $100 \mathrm{pCi} / \mathrm{L}^{\mathrm{b}}$ \\
\hline${ }^{60} \mathrm{Co}$ & $260 \pm 30 \mathrm{~Bq} / \mathrm{L}$ & $<1 \mathrm{~Bq} / \mathrm{L}$ & $200 \mathrm{pCi} / \mathrm{L}$ \\
\hline${ }^{90} \mathrm{Sr}$ & & & $50 \mathrm{pCi} / \mathrm{L}$ \\
\hline
\end{tabular}

"Superfund Health Effects Assessment Summary Tables and User's Guide, Office of Emergency and Remedial Response, USEPA, Washington, D.C., October 1989.

Based on 4 mrem annual dose for drinking water pathway. Federal Register, vol. 51, pp. 34836-34862. 
APPENDIX B

CURRENT SAMPLES 
Current serpese

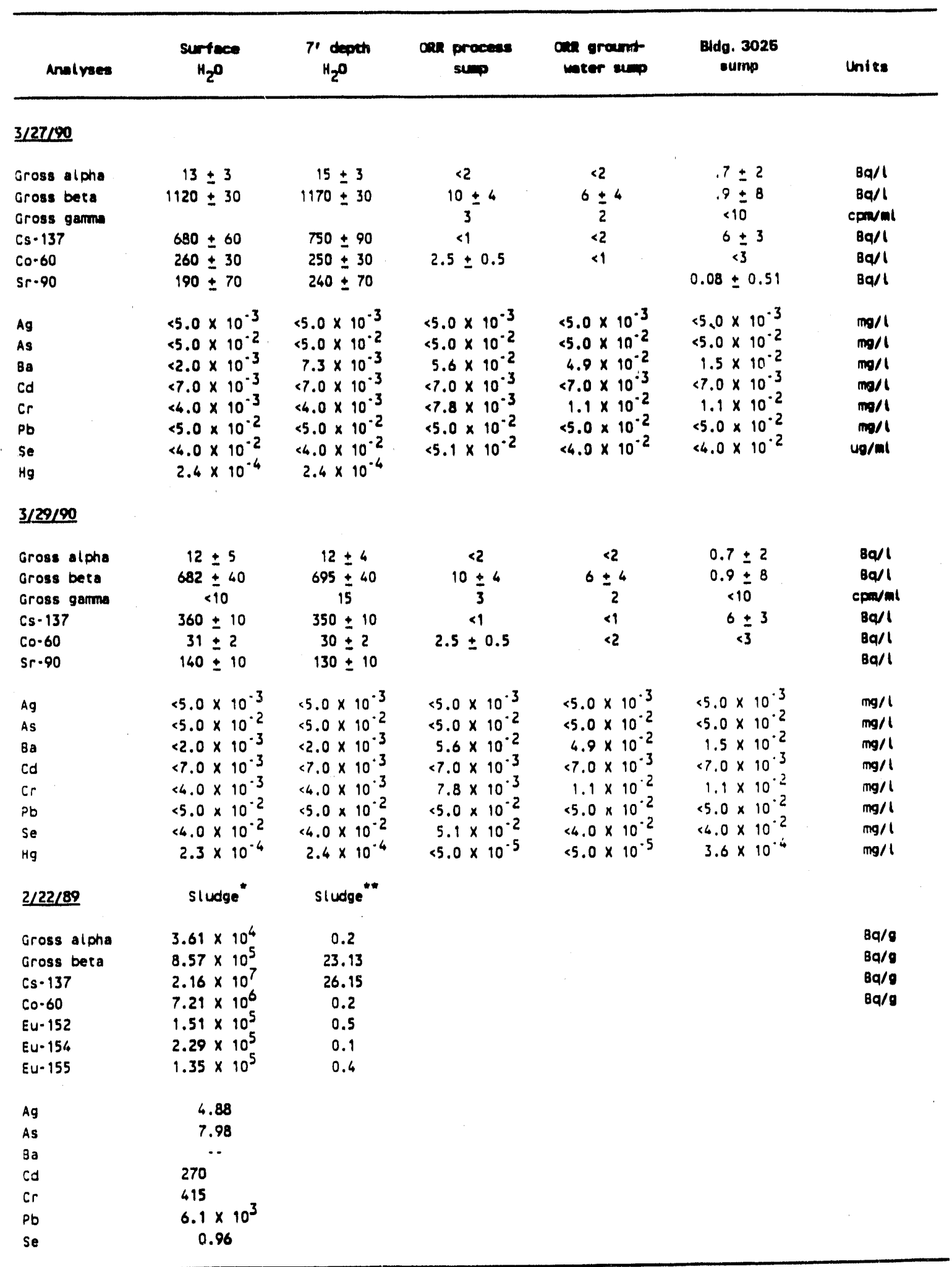

"Averaged from residus.

Averaged from fillerate. 
APPENDIX C

RADIATION WORK PERMITS 


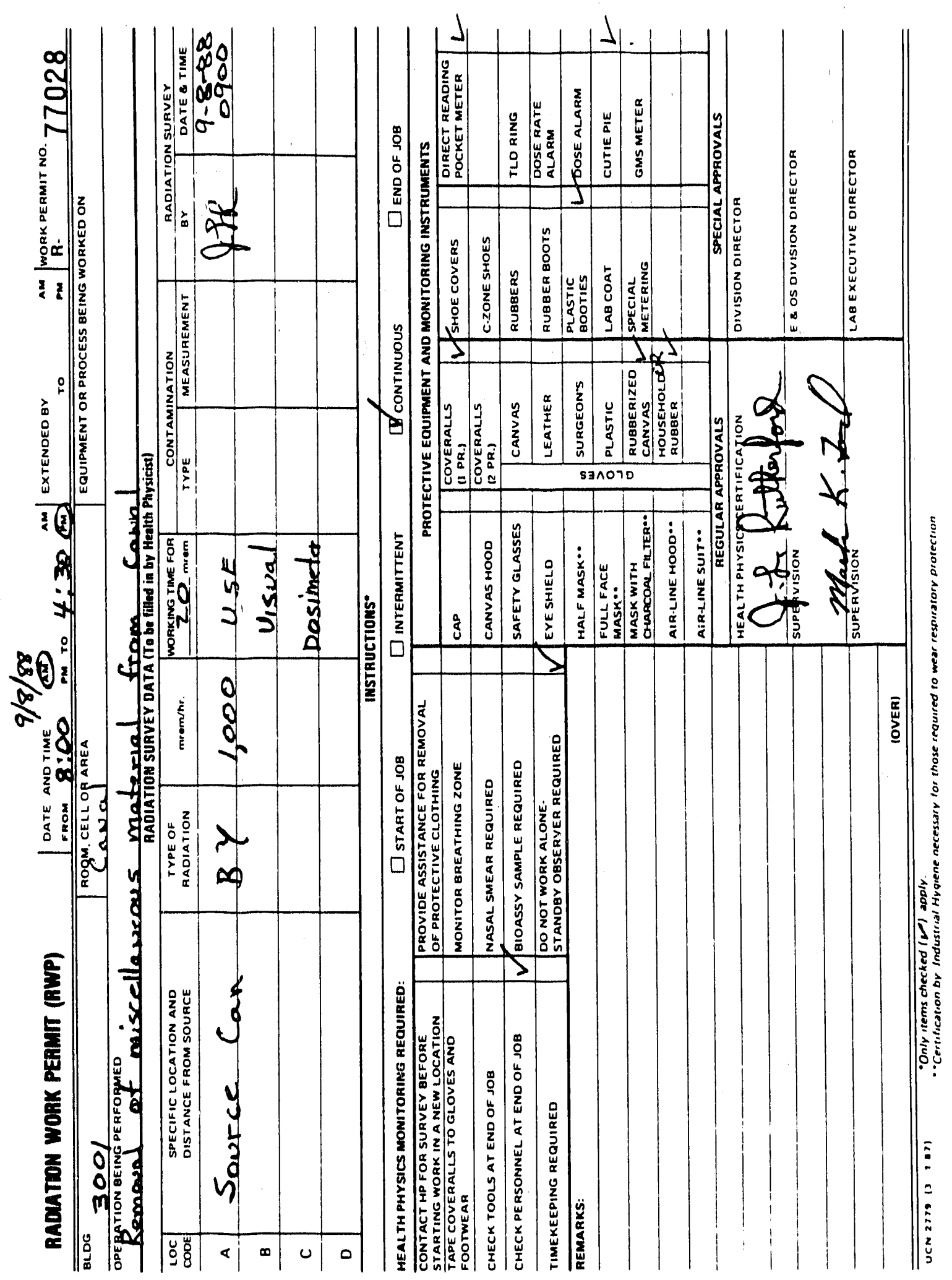




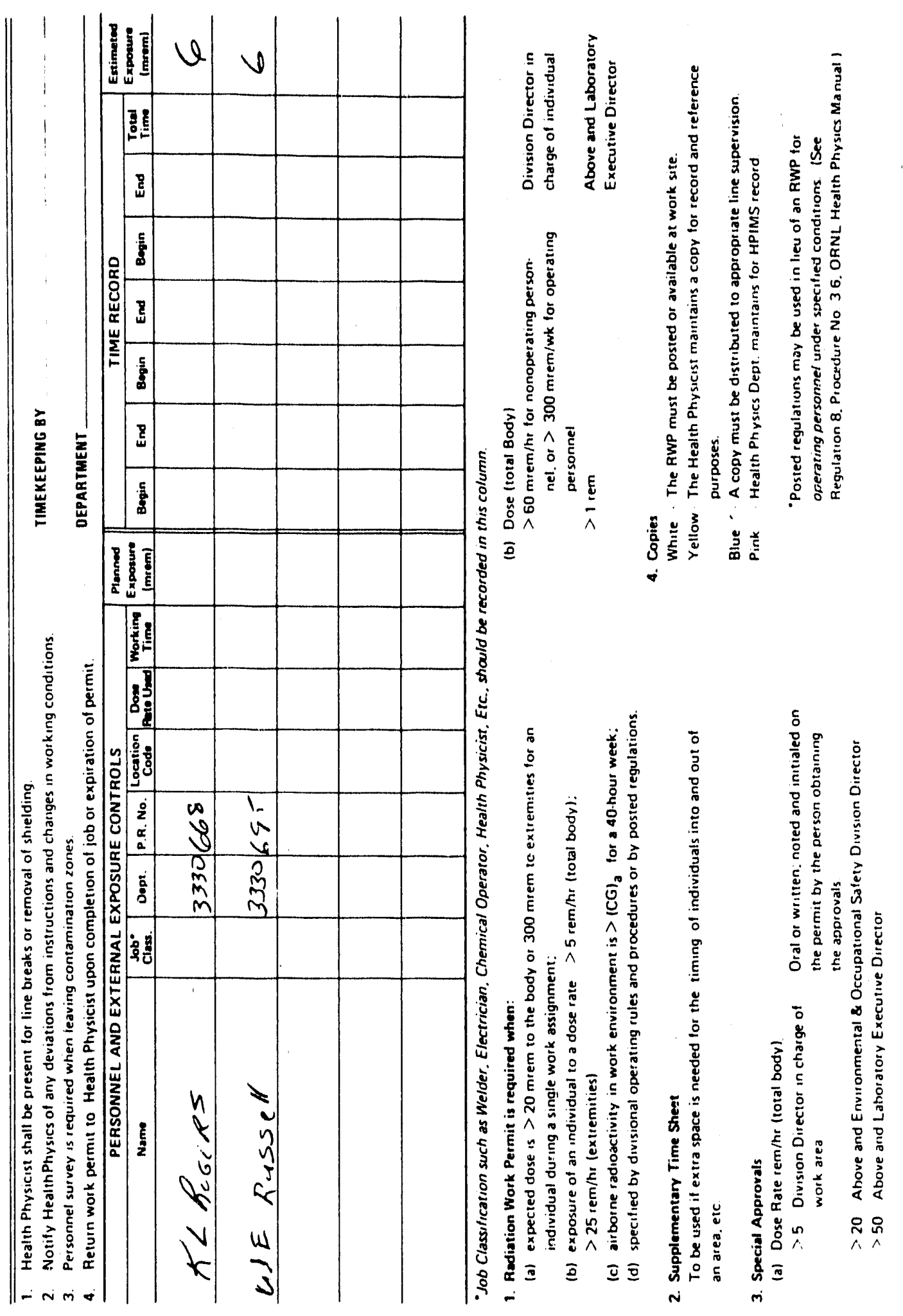




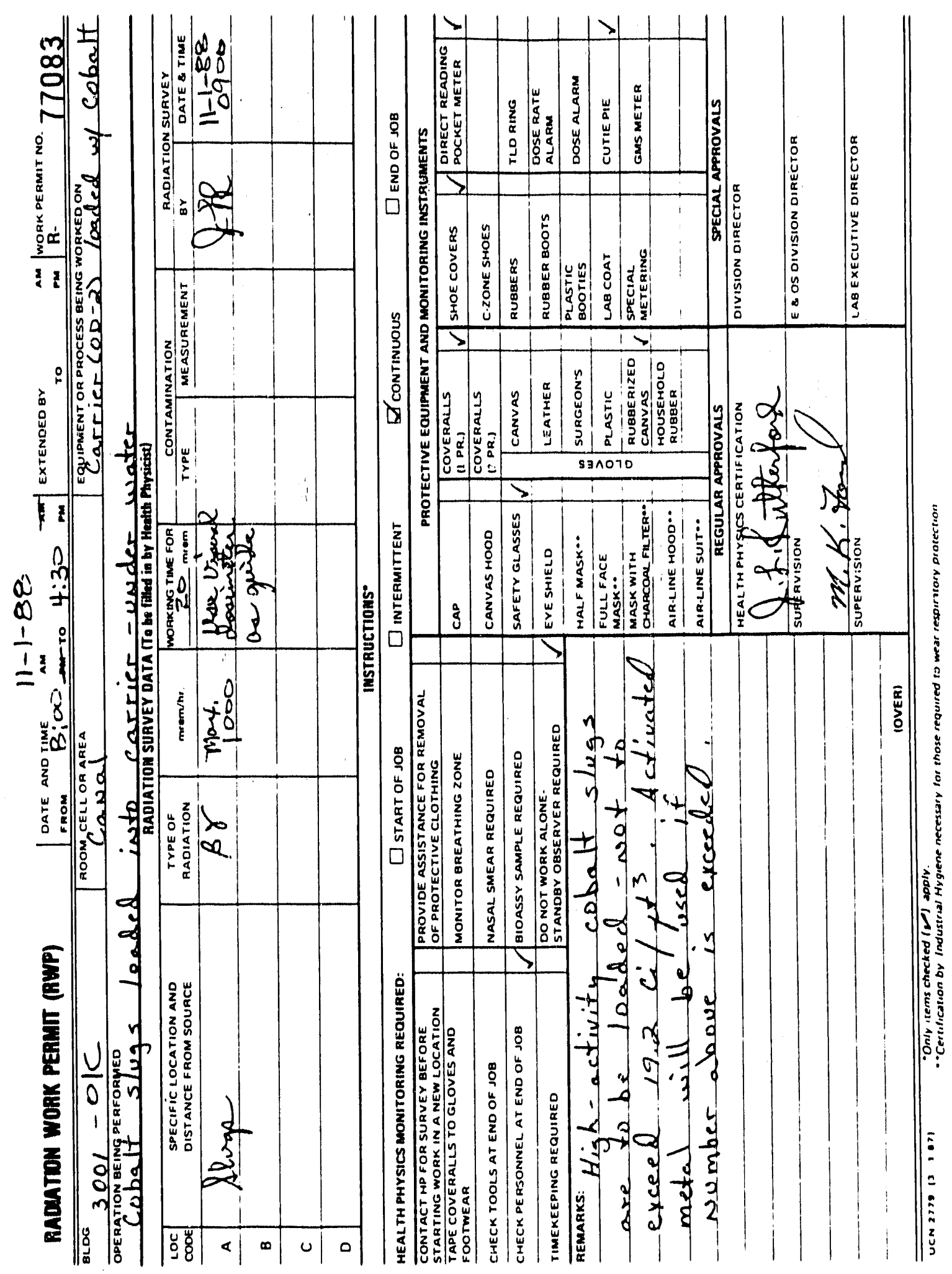




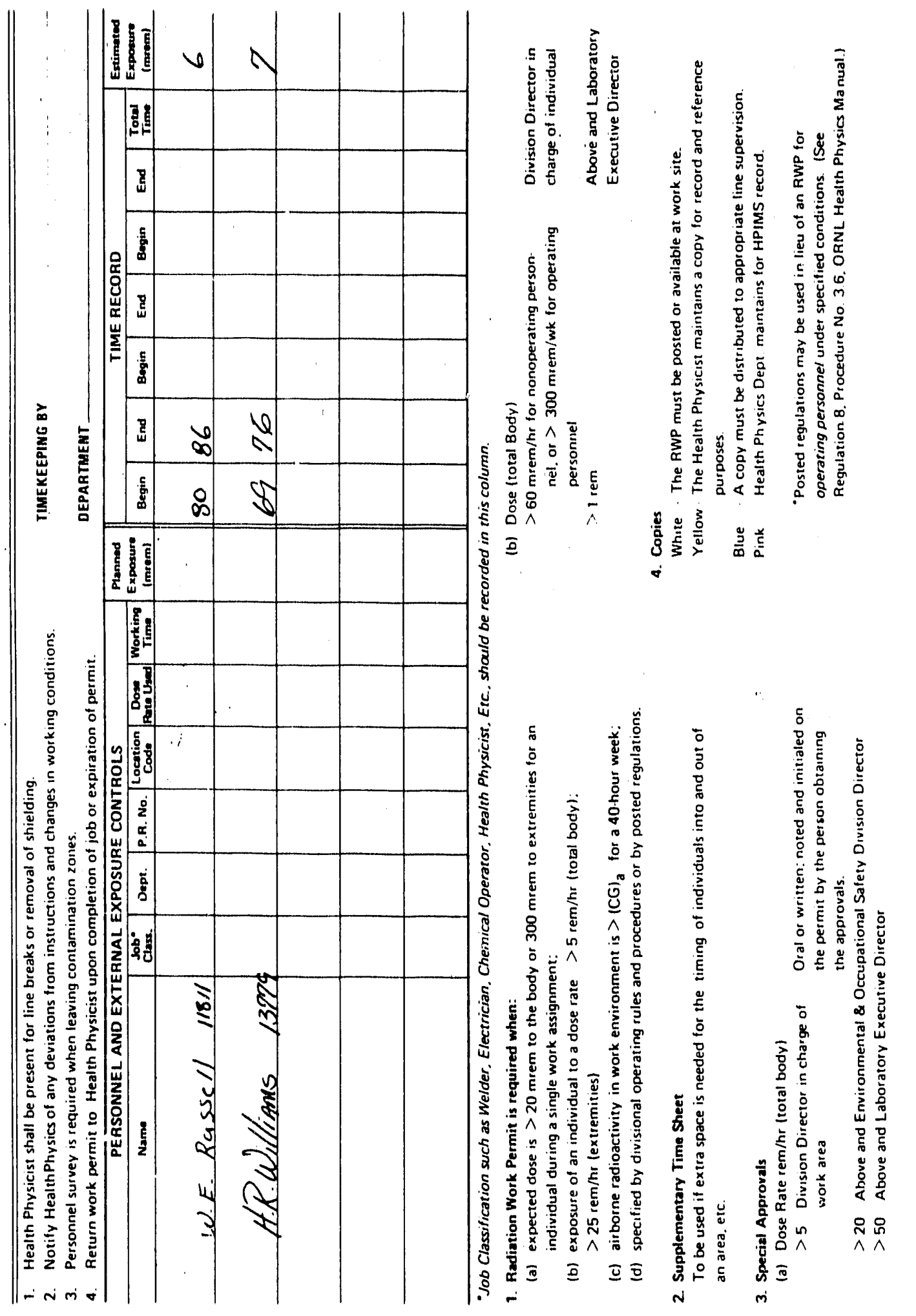




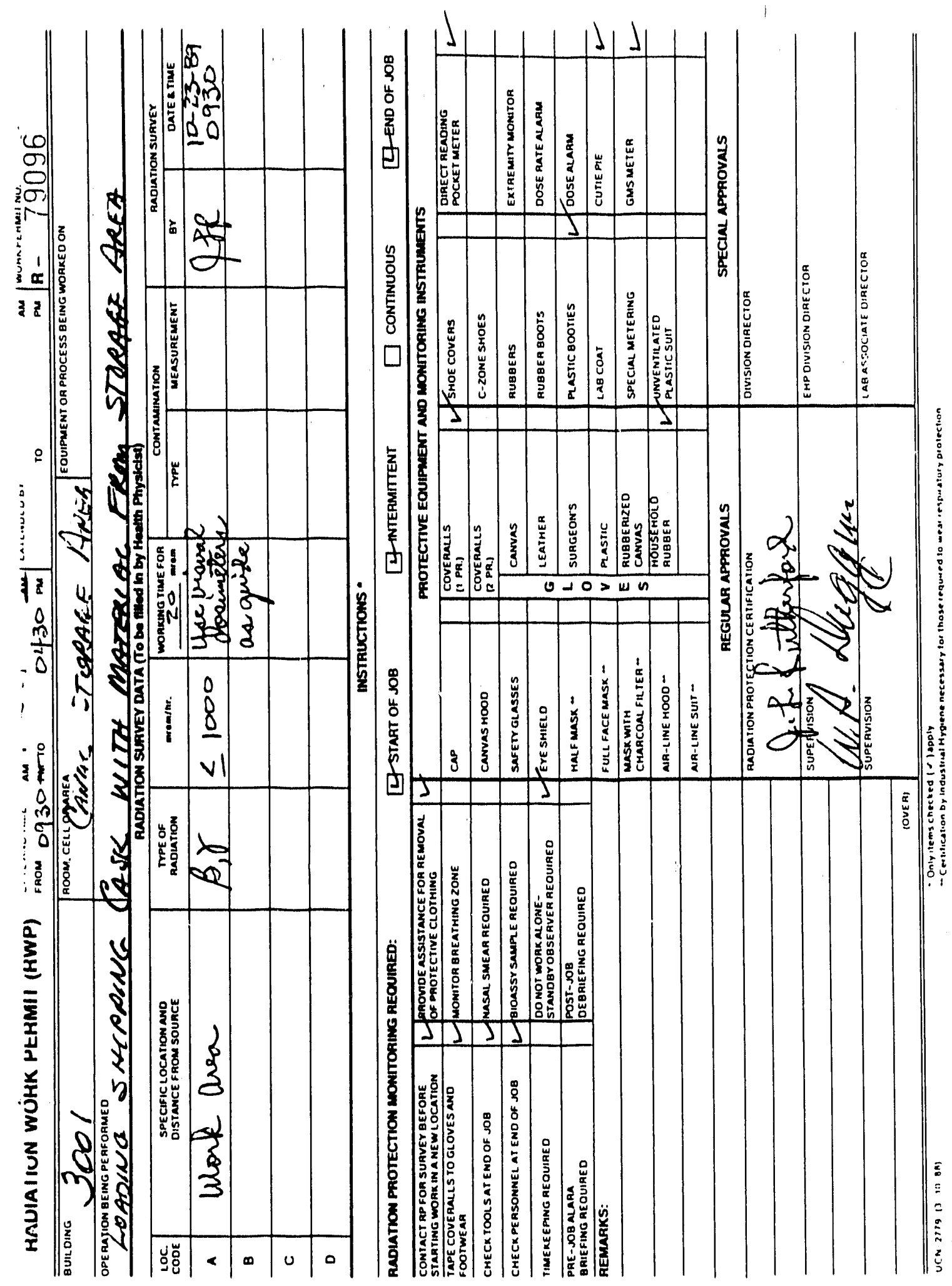




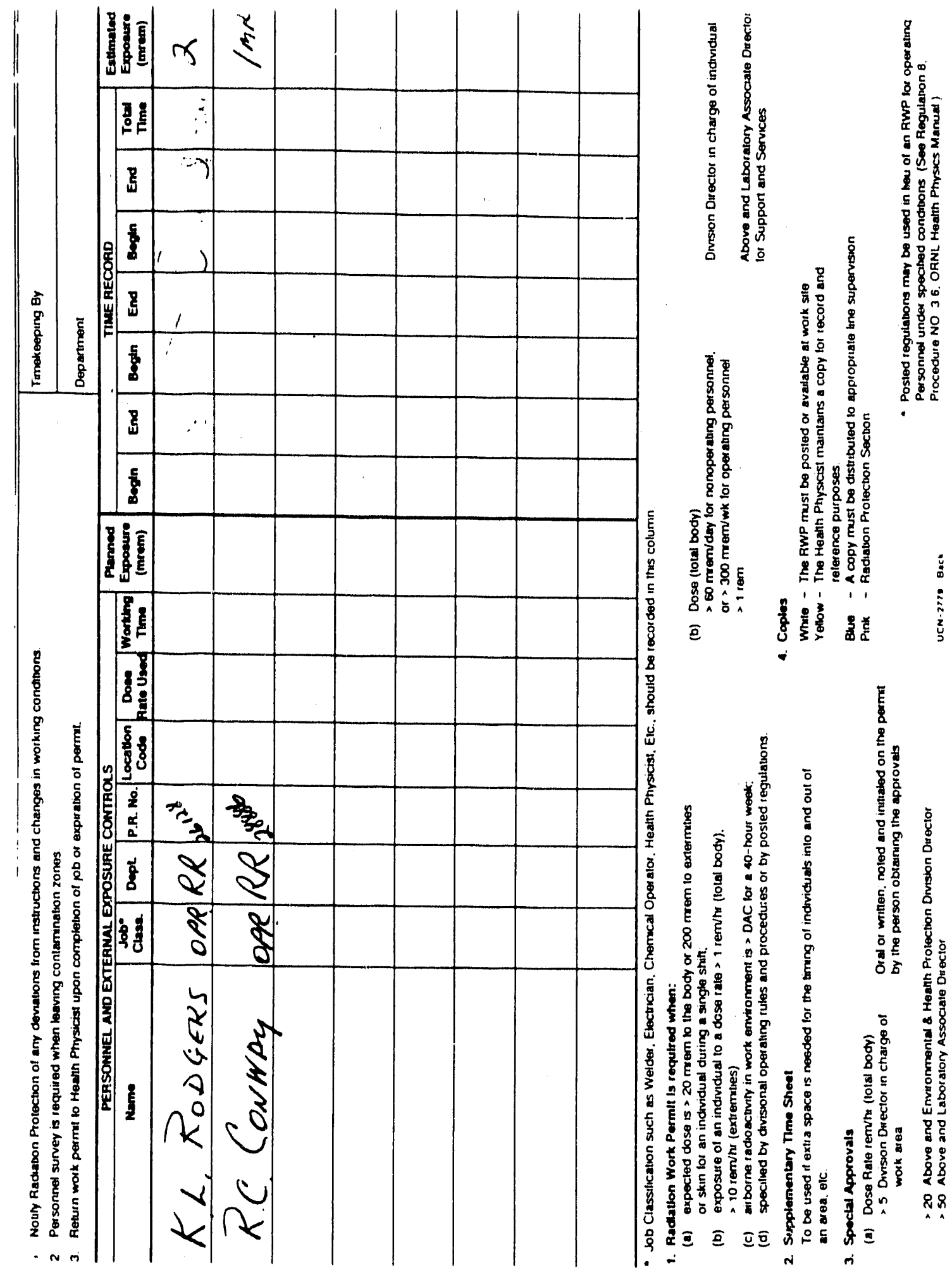




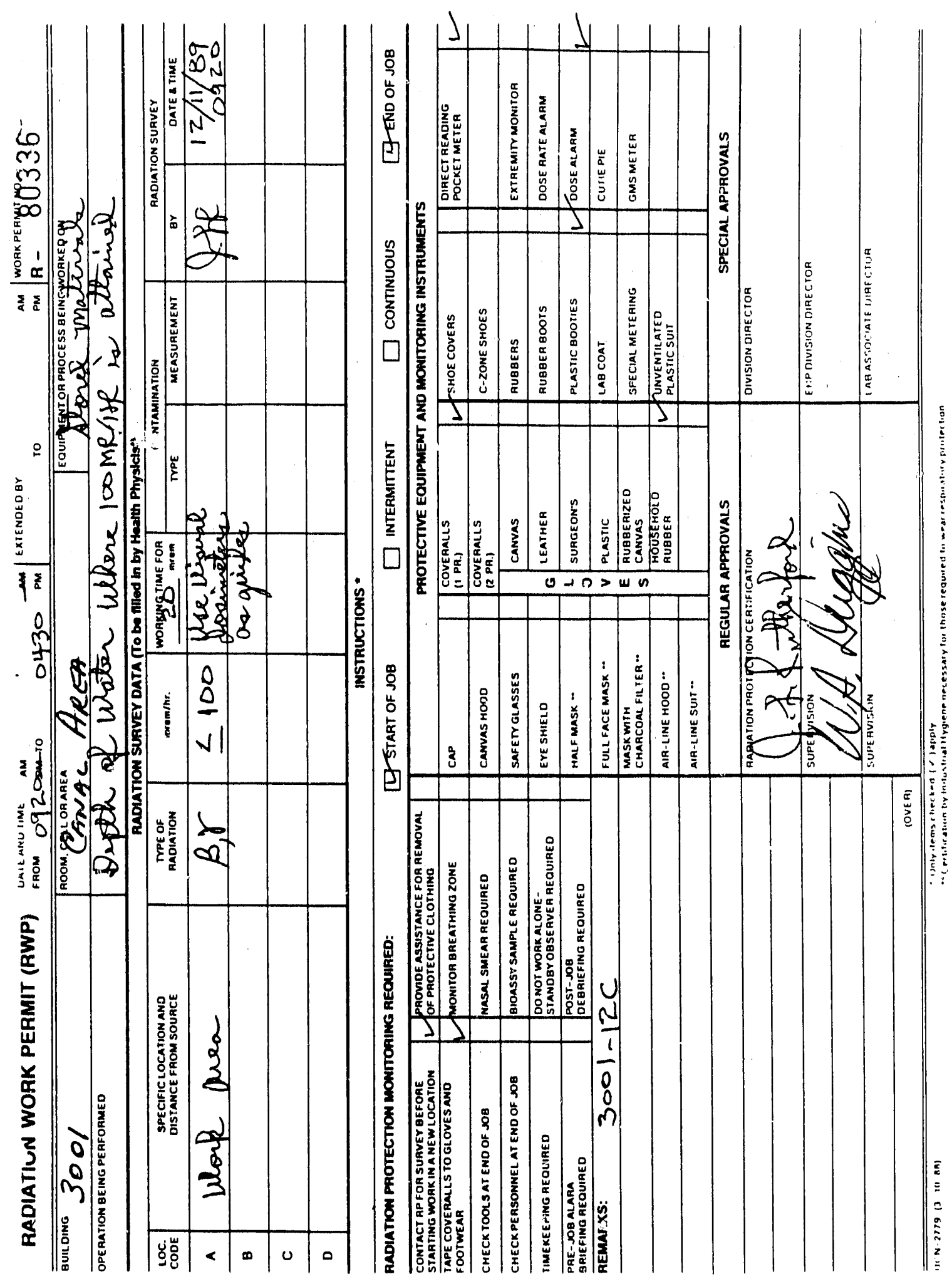




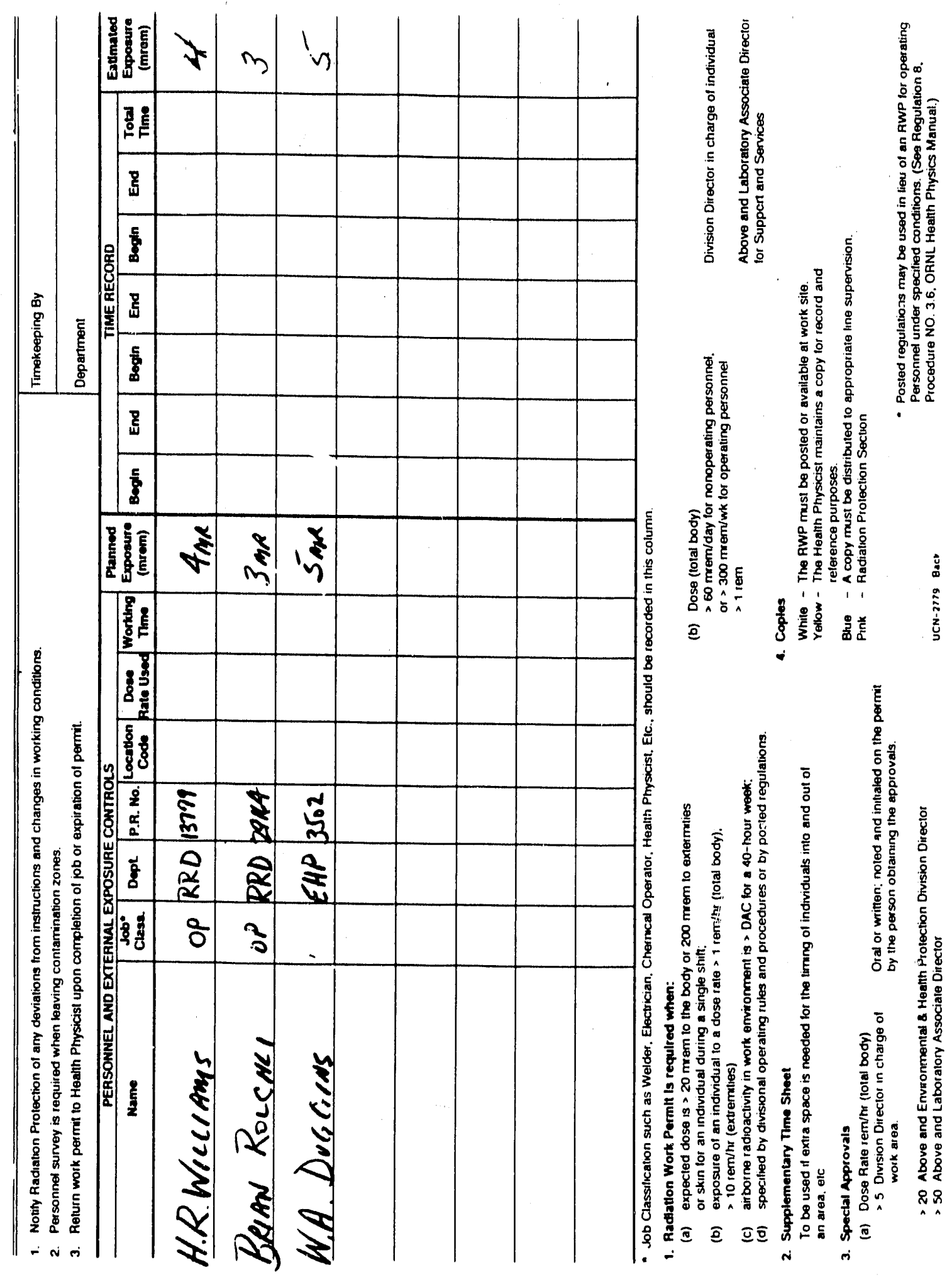


ORNL/ER-51

\section{DISTRIBUTION}

1. L. V. Asplund/N. W. Durfee

2. J. W. Autrey

3. L. D. Bates

4. H. M. Braunstein

5. T. H. Burwinkle

6. H. M. Butler, Jr.

7-11. V. Chidambariah

12. K. W. Cook

13. G. E. Eidam

14. S. B. Garland II

15. C. D. Goins

16. K. G. Greer, Jr.

17. J. S. Greer

18. D. D. Huff

19. L. L. Kaiser

20. M. W. Kohring

21. F. C. Kornegay

22. E. H. Krieg, Jr.

23. J. R. Lawson

24. G. J. Mandry

25. C. P. Manrod

26. R. C. Mason

27. L. E. McNeese

28. C. E. Nix

29. F. R. O’Donnell
30-31. P. T. Owen

32. S. M. Robinson

33. T. H. Row

34. G. E. Rymer

35. T. F. Scanlan

36. P. A. Schrandt

37. C. B. Scott

38. J. A. Setaro

39. G. W. Sherrill

40. C. L. Stair

41. B. H. Stelson

42. L. H. Stinton

43. J. H. Swanks

44. D. W. Swindle

45. J. K. Thomas

46. W. T. Thompson

47. J. R. Trabalka

48. C. C. Travis

49. D. R. Watkins

50. R. K. White

51. Central Research Library

52-53. Laboratory Records Dept.

54. ORNL Patent Section

55-59. ER Document Management Center

60. Office of Assistant Manager for Energy Research and Development, DOE Oak Ridge Field Office, P.O. Box 2001, Oak Ridge, TN 37831-8600

61. P. H. Edmonds, Radian Corporation, 120 South Jefferson Circle, Oak Ridge, TN 37830

62. G. R. Hudson, DOE Oak Ridge Field Office, P.O. Box 2001, Oak Ridge, TN 37831-8541

63. J. R. Kannard, Program Manager, Bechtel National, Inc., P.O. Box 350, Oak Ridge Corporate Center, 151 Lafayette Drive, Oak Ridge, TN 37830

64-67. W. E. Murphie, Department of Energy, Office of Environmental Restoration, Eastern Area D\&D Branch, EM-423 (GTN), Washington, DC 2.0545

68-69. S. S. Perkins, DOE Oak Ridge Field Office, Information Resource Center, Administrative Record File, 105 Broadway, Oak Ridge, TN 37830

70-71. S. P. Riddle, DOE Oak Ridge Field Office, P.O. Box 2001, Oak Ridge, TN 37831-8541

72. R. C. Sleeman, DOE Oak Ridge Field Office, P.O. Box 2001, Oak Ridge, TN 37831-8541

73. J. T. Sweeney, DOE Oak Ridge Field Office, P.O. Box 2001, Oak Ridge, TN 37831-8541

74-75. Office of Scientific and Technical Information, P.O. Box 62, Oak Ridge, TN 37831 

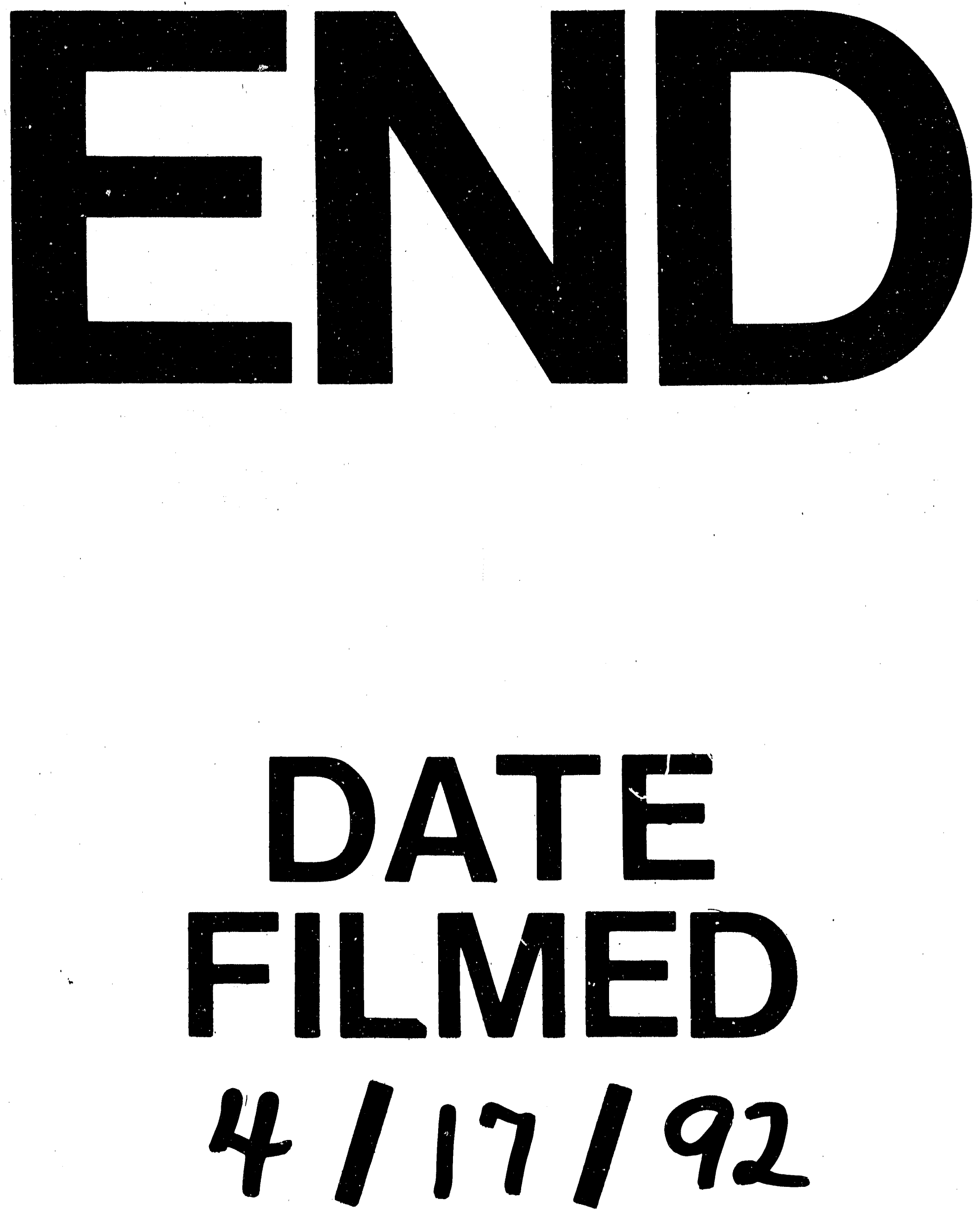

i 
